\title{
Determining the probable role of ferroptosis in the course of inflammatory bacterial diseases of the respiratory organs in young children accompanied by the development of anemia of inflammation
}

\author{
H. 0. Lezhenko*1,A,E,F, O. Ye. Abaturover,A,E, A. O. Pogribna*1,B-D
}

${ }^{1}$ Zaporizhzhia State Medical University, Ukraine, ${ }^{2}$ Dnipro State Medical University, Ukraine

A - research concept and design; B - collection and/or assembly of data; C - data analysis and interpretation; D - writing the article; $\mathrm{E}$ - critical revision of the article; $\mathrm{F}$ - final approval of the article

Key words: ferroptosis, acute inflammatory diseases, anemia, young children.

Pathologia 2021; 18 (1), 44-49

*E-mail: a.pogrebnaia@ gmail.com
Aim. To determine the probable role of ferroptosis in the course of inflammatory bacterial diseases of the respiratory system in young children, accompanied by the development of anemia of inflammation.

Materials and methods. The study included 62 children (mean age $1.4 \pm 0.4$ years). The main group included 42 children with acute inflammatory bacterial diseases of the respiratory system, accompanied by anemia of inflammation: 29 children were diagnosed with bacterial bronchitis, 13 children - pneumonia. Determination of the severity of inflammatory diseases was determined by Acute Bronchitis Severity Score and Pediatric Respiratory Severity Score. At the time of participation in the study, all patients under observation had no signs of impaired iron metabolism, including iron deficiency anemia, in the anamnesis. The control group included 20 relatively healthy children. The content of caspase-7, caspase- 9 , ferritin, nitrotyrosine, phospholipase $A_{2}$ was determined by ELISA using commercial kits.

Results. We hypothesized the ineffectiveness of apoptosis in the course of bacterial inflammatory processes of the respiratory organs in young children, accompanied by the development of anemia of inflammation, and studied the probability of ferroptosis in these conditions. The obtained data indicated the presence of active oxidative stress in the main group patients. The strong direct correlation between the severity of inflammatory disease and the intensity of oxidative stress was revealed $(r=0.7$, $P<0.001)$. A statistically significant increase in ferritin content in the main group compared with the control group was observed. There was a strong direct correlation between ferritin levels and the severity of bronchitis $(r=0.82, P<0.01)$ and the severity of pneumonia $(r=0.87, P<0.01)$. It was found that the upper quartile of serum ferritin levels $(73.2 \pm 4.6 \mathrm{ng} / \mathrm{ml})$ was associated with severe disease. We assumed that restriction of access to iron for bacterial pathogens due to its sequestration in cells is a pathological process under certain conditions.

Conclusions. In the pathogenesis of bacterial inflammatory diseases of the respiratory organs in young children, accompanied by the development of anemia of inflammation, the processes of apoptosis did not dominate, but, obviously, necrotic phenomena did, including ferroptosis as one of the manifestations of necrosis. The protective mechanism aimed at limiting the access of bacterial pathogens to iron due to its sequestration in cells becomes pathological under certain conditions.
Киючові слова: фероптоз, гострі запальні захворювання, анемія, діти раннього віку.

Патологія. 2021. T. 18, № 1(51).

C. $44-49$

\section{Визначення ймовірної ролі фероптозу в перебігу запальних бактеріальних захворювань органів дихання в дітей раннього віку, що супроводжувалися розвитком анемії запалення}

\section{Г. О. Аеженко, О. Є. Абатуров, А. О. Погрібна}

Мета роботи -визначити ймовірну роль фероптозу в перебігу запальних бактеріальних захворювань органів дихання в дітей раннього віку, що супроводжувалися розвитком анемії запалення.

Матеріали та методи. У дослідження залучили 62 дитини (середній вік $-1,4 \pm 0,4$ року). В основну групу включили 42 хворих на гострі запальні бактеріальні захворювання органів дихання, що супроводжувалися анемією запалення: $y$ 29 дітей діагностували бактеріальний бронхіт, у 13 -пневмонію. Тяжкість перебігу запальних захворювань визначали за шкалами Acute Bronchitis Severity Score та Pediatric Respiratory Severity Score. На момент участі в дослідженні в усіх пацієнтів, які перебували під спостереженням, в анамнезі не було ознак порушення обміну заліза, зокрема залізодефіцитної анемії. Контрольна група - 20 умовно здорових дітей. Методом ІФА визначали вміст каспази-7, каспази-9, феритину, нітротирозину, фосфоліпази А 3 використанням комерційних наборів.

Результати. Припустили неефективність апоптозу в перебігу бактеріальних запальних процесів органів дихання в дітей раннього віку, що супроводжувалися розвитком анемії запалення, та вивчали ймовірність розвитку фрероптозу в цих умовах. Результати свідчили про наявність активного оксидативного стресу в пацієнтів основної групи. Визначили сильний прямий кореляційний зв'язок між тяжкістю запального захворювання та інтенсивністю оксидативного стресу $(r=0,7, p<0,001)$. Спостерігали статистично значуще підвищення вмісту феритину в основній групі дослідження порівняно з групою контролю. Виявили сильний прямий зв'язок між рівнем фреритину та тяжкістю перебігу бронхіту $(r=0,82, p<0,01)$, тяжкістю перебігу пневмонії $(r=0,87, p<0,01)$. З'ясували, що верхній квартиль рівня фреритину в сироватці крові $(73,2 \pm$ 4,6 нг/мл) асоціювався з важким перебігом хвороби. Припустили, що захисний механізм, спрямований на обмеження доступу бактеріальних патогенів до заліза внаслідок його секвестрації у клітинах, передусім у макрофагах, за певних умов стає патологічним. 
Висновки. У патогенезі бактеріальних запальних захворювань органів дихання в дітей раннього віку, що супроводжувалися розвитком анемії запалення, домінували не процеси апоптозу, а, вочевидь, некротичні явища, зокрема фероптоз як один із проявів некрозу. Захисний механізм, спрямований на обмеження доступу бактеріальних патогенів до заліза внаслідок його секвестрації у клітинах, за певних умов стає патологічним.

\section{Определение вероятной роли ферроптоза в течении воспалительных бактериальных заболеваний органов дыхания у детей раннего возраста, которые сопровождались развитием анемии воспаления}

\section{Г. А. Аеженко, А. Е. Абатуров, А. А. Погребная}

Цель работы - определить вероятную роль ферроптоза в течении воспалительных бактериальных заболеваний органов дыхания у детей раннего возраста, сопровождавшихся развитием анемии воспаления.

Материалы и методы. В исследование включили 62 ребенка (средний возраст $-1,4 \pm 0,4$ года). Основную группу составили 42 пациента с острыми воспалительными бактериальными заболеваниями органов дыхания, сопровождавшихся анемией воспаления: у 29 детей диагностирован бактериальный бронхит, у 13 - пневмония. Тяжесть течения воспалительных заболеваний определяли по шкалам Acute Bronchitis Severity Score и Pediatric Respiratory Severity Score. На момент участия в исследовании у всех пациентов в анамнезе не было признаков нарушения обмена железа, в том числе железодефицитной анемии. Контрольную группу составили 20 условно здоровых детей. Методом ИФА определяли содержание каспазы-7, каспазы-9, ферритина, нитротирозина, фоосфолипазы $A_{2}$ с использованием коммерческих наборов.

Результаты. Предположили неэффективность апоптоза в течении бактериальных воспалительных процессов органов дыхания у детей раннего возраста, сопровождавшихся развитием анемии воспаления, изучали вероятность развития ферроптоза в данных условиях. Результаты указывали на наличие активного оксидативного стресса у пациентов основной группы. Отмечено наличие сильной прямой корреляционной связи между тяжестью воспалительного заболевания и интенсивностью оксидативного стресса ( $r=0,7, p<0,001)$. Наблюдали статистически значимое повышение содержания фрерритина в основной группе исследования по сравнению с группой контроля. Отмечена сильная прямая связь между уровнем ферритина и тяжестью течения бронхита ( $r=0,82, p<0,01)$, тяжестью течения пневмонии $(r=0,87, p<0,01)$. Установлено, что верхний квартиль уровня ферритина в сыворотке крови $(73,2 \pm 4,6$ нг/мл) ассоциировался с тяжелым течением заболевания. Предположили, что защитный механизм, направленный на ограничение доступа бактериальных патогенов к железу за счет его секвестрации в клетках, в первую очередь макрофрагах, при определенных условиях становится патологическим.

Выводы. В патогенезе бактериальных воспалительных заболеваний органов дыхания у детей раннего возраста, сопровождавшихся развитием анемии воспаления, доминировали не процессы апоптоза, а, очевидно, некротические явления, в том числе ферроптоз как одно из проявлений некроза. Защитный механизм, направленный на ограничение доступа бактериальных патогенов к железу за счет его секвестрации в клетках, при определенных условиях становится патологическим.

Over the past two decades, researchers have studied various forms of regulated cell death. Previously, the understanding of cell death was limited to the concepts of apoptosis as a form of programmed death, and necrosis as accidental, unregulated cell death [1]. At least 12 different types are currently known, one of which is ferroptosis [2]. The term "ferroptosis" was first defined in 2012 when Dixon S.J. et al. reported the phenomenon of non-apoptotic regulated cell death [3]. Brent $\mathrm{R}$. et al. identified ferroptosis as catalytic, dependent on $\mathrm{Fe}^{2+}$, regulated necrosis associated with lipid peroxidation [4]. The leading inducers of ferroptosis are the active forms of oxygen formed during the Fenton reaction - the transformation of $\mathrm{Fe}^{2+}$ into $\mathrm{Fe}^{3+}$. The Fenton reaction is characterized by the fact that excess iron, which is not bound to ferritin or ferroportin, generates a hydroxyl radical. The reactivity of the hydroxyl radical is extremely high: it is capable of oxidizing almost any substance in the cell, including DNA, proteins, lipids [5]. Under the action of the final products of lipid peroxidation, phospholipase $\mathrm{A}_{2}$ is activated, the substrate of which is phospholipids of cell membranes. After their hydrolysis and cleavage from phospholipids of free fatty acids, mediators of a wide range of cellular processes of proinflammatory nature are formed. The formation of products of hydrolysis of phospholipids, including phospholipase $A_{2}$, contributes to the development of the inflammatory process [6]. Cell death caused solely by ferroptosis can be inhibited by iron chelators, lipophilic antioxidants and lipid peroxidation inhibitors, and correlates with the accumulation of markers of lipid peroxidation [4]. The process of accumulation of lipid peroxides, which plays a significant role in the implementation of ferroptosis, requires a significant supply of iron, so the import, export, turnover of iron affect the sensitivity of ferroptosis. Taking into account that anemia of inflammation (Al) has an iron-redistributive genesis, the study of the ferroptosis process becomes relevant for our study.

\section{Aim}

To determine the probable role of ferroptosis in the course of inflammatory bacterial diseases of the respiratory system in young children, accompanied by the Al development.

\section{Materials and methods}

The study groups included 62 young children (average $1.4 \pm 0.4$ years). Children who were under observa-
Ключевые слова: ферроптоз, острые воспалительные заболевания, анемия, Аети раннего возраста.

Патология. 2021

T. 18, № 1(51).

C. $44-49$ 
tion were examined in the Communal non-commercial enterprise "Zaporizhzhia Regional Clinical Children's Hospital" of the Zaporizhzhia Regional Council (director Yu. V. Borzenko). The main study group consisted of 42 children with acute inflammatory bacterial respiratory diseases. They were diagnosed with Al 4-5 days after the onset of the disease. In 29 children bacterial bronchitis developed, in 13 children - pneumonia. Acute Bronchitis Severity Score (ABSS) was used to determine the severity of acute bronchitis [7]: 17 (58.62\%) children had moderate to severe disease, 12 (41.38\%) children had severe one. Pediatric Respiratory Severity Score (PRESS) was used to determine the severity of acute pneumonia [8]: $5(38.46 \%)$ children had a moderate severe disease, 8 $(61.54 \%)$ children had a severe disease. At the time of participation in the study, all patients under observation had no signs of impaired iron metabolism, including iron deficiency anemia, in the anamnesis. The control group consisted of 20 relatively healthy children. The study groups were representative by age and sex.

The content of caspase-7, caspase-9, ferritin, nitrotyrosine, phospholipase $A_{2}$ was determined by enzyme-linked immunosorbent assay (ELISA) using commercial kits: RayBio Human CASP7 ELISA Kit (RayBiotech, U.S.A.); Human Caspase-9 ELISA Kit (Bender MedSystems GmbH, Austria); Ferritin ELISA (ORGENTEC Diagnostika GmbH, Germany); Nitrotyrosine, ELISA (HucultBiotech); Enzyme-Linked Immunosorbent Assay (ELISA) Kit For Phospholipase A2 Lipoprotein Associated (LpPLA2). The studies were carried out at the Training Medical and Laboratory Center (TMLC) of Zaporizhzhia State Medical University (the Head of TMLC - MD, PhD, DSc, Professor A. V. Abramov).

Mathematical analysis and statistical data processing were performed using a licensed software package Statistica for Windows 13.0 (JPZ8041382130ARCN10-J). Normality of the data was checked using the ShapiroWilk test. We used the method of correlation analysis with the Spearman's correlation coefficient calculation. Measurement data of a non-normal distribution and non-linear dependence were expressed as a median and quartile $\left(\mathrm{Me}\left(\mathrm{Q}_{25} ; \mathrm{Q}_{75}\right)\right)$. To assess the differences in indicators, the nonparametric Mann-Whitney U-test was calculated as a nonparametric analogue of the Student criterion. Differences were considered at a significance level of $\mathrm{P}<0.05$.

All procedures performed in studies involving human participants were in accordance with the ethical standards of the institutional and national research committee and with the 1964 Helsinki declaration and its later amendments or comparable ethical standards. Informed consent was obtained from all individual participants included in the study. The full data set by children, their parents, and physician that support the findings of this study are not publicly available due to the restrictions of the ethics approval originally obtained.

\section{Results}

In a previous study, we investigated the activity of apoptosis markers in children diagnosed with Al on the background of bacterial infections of the respiratory tract. We observed the activation of the first link of apoptosis - initialization - due to an increase in the content of caspase- 9 in the serum of children in the main study group compared with the control group. But the levels of caspase-7, which is a marker of activation of the effector link of the "caspase cascade", did not have a statistically significant difference between the study groups. This allowed us to assume the ineffectiveness of apoptosis in the course of bacterial inflammatory processes of the respiratory organs in young children, accompanied by the development of $\mathrm{Al}$, and to predict a high probability that its development will be dominated by necrosis or other cell death mechanisms [9]. Necrosis occurs without the involvement of the caspase system and can take various forms. Based on the obtained data, which indicated the activation of the protective mechanism that occurs against the background of bacterial inflammatory process, i.e. processes of active iron deposition, we suggested that in these conditions the development of one form of necrosis, namely ferroptosis, is possible.

This type of programmed cell death develops in the presence of a number of causes, and, above all, the activation of oxidative stress, and in the presence of iron ions, which acts as a catalyst for the process. During the development of anemia of inflammation, a significant amount of iron ions is sequestered in cells, primarily in macrophages [1]. Thus, the stages of work were divided into two areas: determining the activity of oxidative stress and the study of iron deposition and the activity of the inflammatory process.

The results of our earlier study [10] determined the activity of oxidative stress in a group of patients under observation by determining the content of nitrotyrosine and phospholipase $A_{2}$. The data obtained support our hypothesis about the role of ferroptosis during inflammatory bacterial processes in the respiratory organs, which were accompanied by the development of anemia of inflammation, in young children. According to the results of the comparisons, it was found that in children of the main group with diagnosed $\mathrm{Al}$, the content of nitrotyrosine exceeded the control group by 5 times $(62.5(52.5 ; 80.0) \mathrm{ng} / \mathrm{ml}$ та $12.5(8.2 ; 17.2) \mathrm{ng} / \mathrm{ml}$, respectively, $\mathrm{P}<0.01)$ (Fig. 1), phospholipase $\mathrm{A}_{2}$ - by 2.7 times $(6.1(5.7 ; 6.4) \mathrm{ng} / \mathrm{ml}$ and $2.28(2.0 ; 2.8) \mathrm{ng} / \mathrm{ml}$, respectively, $\mathrm{P}<0.05)$ (Fig. 2) [10].

A strong direct correlation between the severity of inflammatory disease and the intensity of oxidative stress was revealed $(r=0.7, P<0.001)$.

Thus, the data obtained indicated the presence of active oxidative stress in young children with inflammatory bacterial diseases of the respiratory system, accompanied by the development of Al. It is known that phospholipase $A_{2}$ is not only a marker of oxidative stress. Lu B. et al. indicate that it synergistically enhances ferroptosis [11]. Taking into account the data on the threefold increase in the level of phospholipase $A_{2}$ in the main group, its role, in this case, acquires a new pathogenetic significance.

Nao Y. research convincingly indicates that the inducer of ferroptosis is the process of ferritinophagy [12]. Therefore, the next stage of the work was the study of ferritin content in children from the observation groups as a marker of accumulation and intracellular redox activity of iron. Today it is known that serum ferritin is an important 

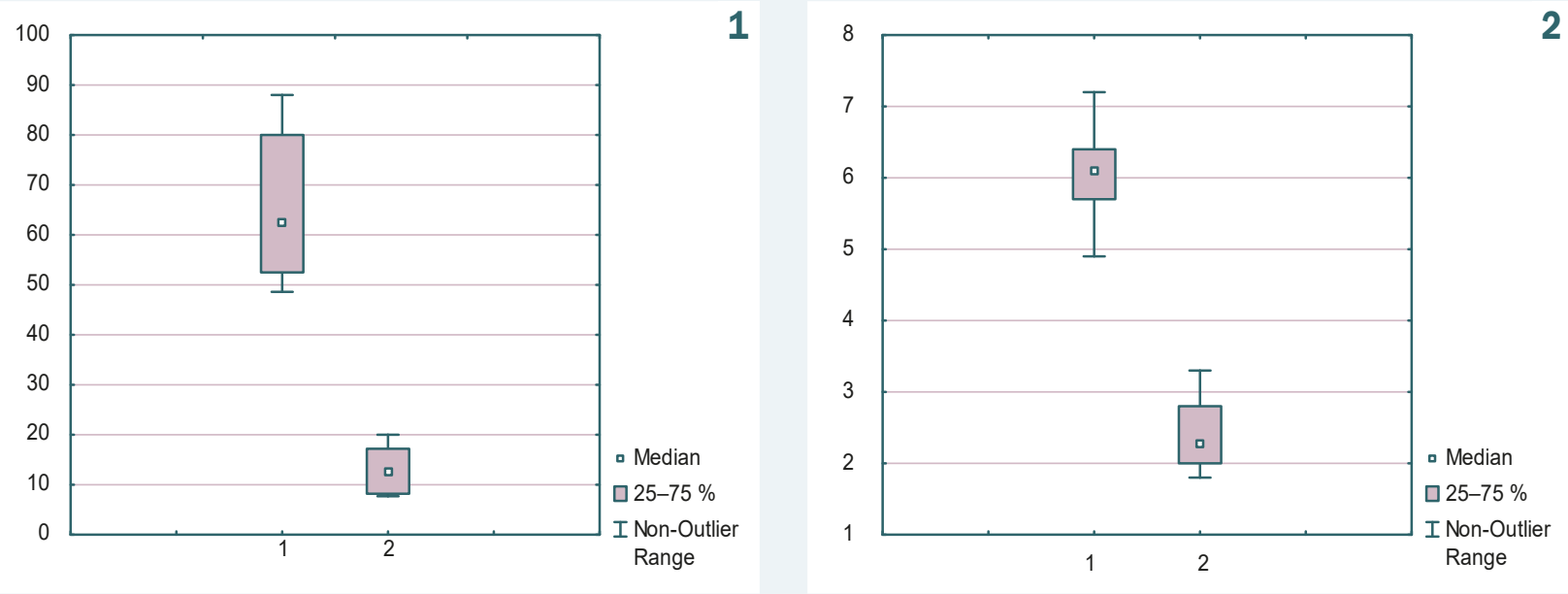

Fig. 1. The content of nitrotyrosine in the children under observation blood serum. 1: the main group; 2: the control group.

Fig. 2. The content of phospholipase $A_{2}$ in the children under observation blood serum. 1: the main group; 2: the control group.
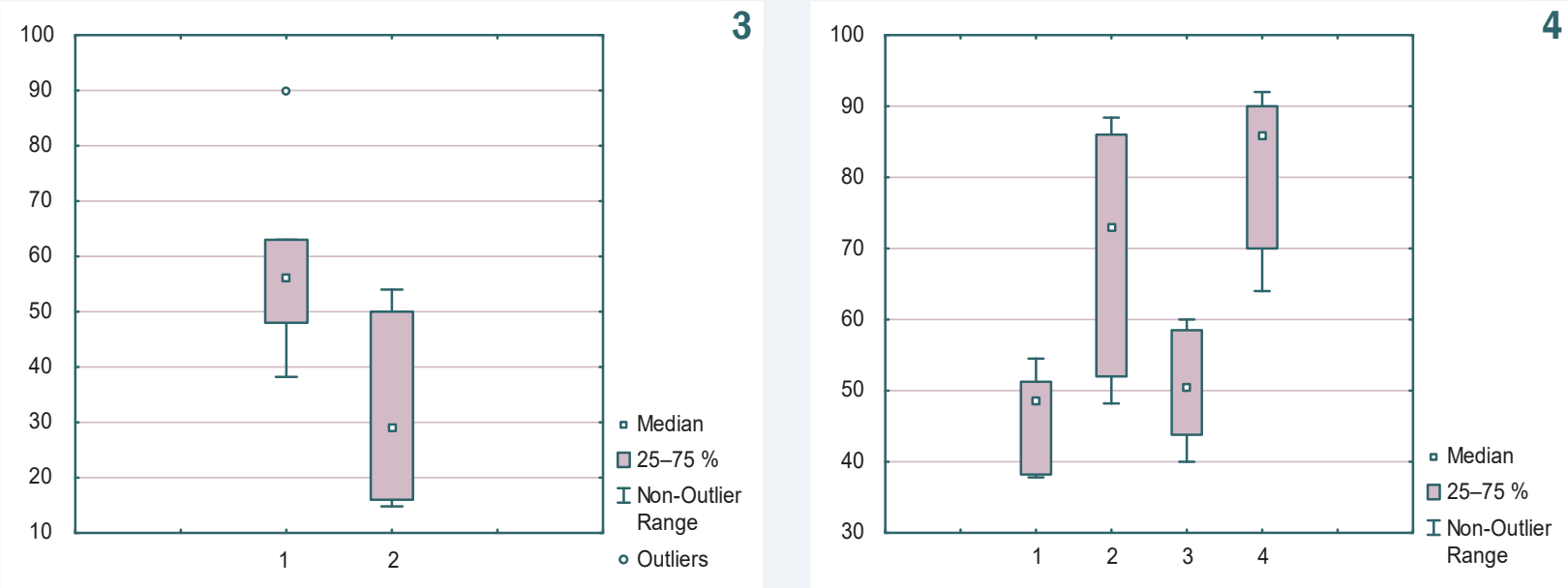

Fig. 3. The content of ferritin in the children under observation blood serum. 1: the main group; 2: the control group.

Fig. 4. The content of ferritin in the main group blood serum depending on the severity of the inflammatory disease. 1: moderate bronchitis; 2 : severe bronchitis; 3 : moderate pneumonia; 4: severe pneumonia.

indicator of iron stores in the body. Ferritin is released from the cells, forming a serum pool in proportion to its content in the tissues.

According to the results of the comparisons, as expected, we observed a statistically significant increase in ferritin content in the main study group compared with the control group $(56.51(48.0 ; 63.0) \mathrm{ng} / \mathrm{ml}$ and 29.0 (16.0; $50.0) \mathrm{ng} / \mathrm{ml}$, respectively, $\mathrm{P}<0.05)$ (Fig. 3) [13].

We found a strong direct correlation between the level of serum ferritin and the severity of bronchitis $(r=0.82$, $P<0.01)$ and the severity of pneumonia $(r=0.87$, $P<0.01)$. The same trend was observed when comparing ferritin levels in children with acute pneumonia: the content of ferritin in severe pneumonia was 1.7 times higher than its level in moderate pneumonia (50.5 (43.8; $58.5) \mathrm{ng} / \mathrm{ml}$ and $85.85(70.0 ; 90.0) \mathrm{ng} / \mathrm{ml}$, respectively, $P<0.05)$ (Fig. 4).

Under these conditions, we hypothesized that the protective mechanism aimed at limiting the access of bacterial pathogens to iron due to its sequestration in cells, and primarily macrophages, under certain conditions becomes pathological. That is, due to the activation of ferroptosis processes there is suppression and the destruction of immune cells (T-lymphocytes) and macrophages, which is a pathogenetic link in the development and causes a severe course of the disease. The fact that serum ferritin is a marker of inflammation and directly correlates with the level of proinflammatory cytokines also supported this assumption [14]. We found that in young children with bacterial inflammatory diseases of the respiratory system accompanied by the development of $\mathrm{Al}$, the calculated upper quartile of serum ferritin levels $(73.2 \pm 4.6 \mathrm{ng} / \mathrm{ml})$ was associated with severe disease.

\section{Discussion}

Caspase-dependent apoptosis was the first regulated programmed form of cell death to be studied at the molecular level. We studied the activity of caspase-dependent apoptosis in young children with bacterial inflammatory 
processes of the respiratory system, accompanied by the development of Al. But it was found that the process of apoptosis in this case was limited to the initialization phase. We have suggested that the inefficiency of apoptosis is due to the intensification of necrotic processes [9], namely the activation of ferroptosis processes. Determination of the activity of oxidative stress in children under supervision, namely this process initiates the start of ferroptosis, showed its high activity. On the other hand, the accumulation of iron in the cytoplasm is a protective mechanism that limits its use by bacterial pathogens for their growth. At the same time, an increase in iron levels can lead to increased oxidative stress and lipid peroxidation, which will provoke iron-dependent programmed cell death. We assume that in this case it is important to deposit iron with ferritin, which keeps its excess in redox inactive form and prevents oxidative damage to cells and tissues $[15,16]$. At present, the mechanisms of iron overload of cells in ferroptosis are not well studied [17], however, it was found that increased levels of cellular labile iron and degradation of ferritin induce its process [12]. But Lei Pengxu et al. suggested that ferritinophagy is an intermediate link in ferroptosis [18], therefore, the high content of ferritin in the study group of children with $\mathrm{Al}$ does not deny the role of ferroptosis in its development.

We investigated the increase in oxidative stress in proportion to the increase in the severity of inflammatory disease. Realizing that oxidative stress is a trigger for ferroptosis, we hypothesized a correlation between it and increasing disease severity. In favor of this assumption is that the morphological features of the course of ferroptosis can lead to a violation of the integrity of the tissue barrier, resulting in possible facilitation of the introduction of bacterial pathogens [19]. It was also investigated that an increase in iron levels is accompanied by an exacerbation of the inflammatory process and an increase in the bacterial load on the lung tissue [20]. Iron sequestration in macrophages has been closely linked to the function of ferroportin, which plays a role in increasing the production of interleukin-6, which is known to induce the production of hepcidin, which plays a special role in the development of Al. The above data demonstrate that the violation of adequate iron metabolism is a common feature of both the inflammatory process and ferroptosis, however, under certain conditions, the process that began as a compensatory is transformed into a pathological, uncontrollable, which contributes to the severe course of the disease.

\section{Conclusions}

1. In the pathogenesis of bacterial inflammatory diseases of the respiratory organs in young children, accompanied by the development of anemia of inflammation, the processes of apoptosis did not dominate, but, obviously, necrotic phenomena did, including ferroptosis as one of the manifestations of necrosis.

2. Restriction of access to iron for bacterial pathogens due to its sequestration in cells can be a pathological process under certain conditions.

3. It was found that in young children with bacterial inflammatory diseases of the respiratory system, accompanied by the development of $\mathrm{Al}$, the calculated upper quartile of serum ferritin levels $(73.2 \pm 4.6 \mathrm{ng} / \mathrm{ml})$ was associated with severe disease.

Funding

The study was conducted by funding Zaporizhzhia State Medical University.

Conflicts of interest: authors have no conflict of interest to declare. Конфлікт інтересів: віАсутній.

НаАійшла Ао редакції / Received: 04.02.2021

Після Аоопрацювання / Revised: 26.02.2021

Прийнято Ао Аруку / Accepted: 09.03.2021

Information about authors:

Lezhenko H. O., MD, PhD, DSc, Head of the Department of Hospital Pediatrics, Zaporizhzhia State Medical University, Ukraine.

Abaturov 0. Ye., MD, PhD, DSc, Head of the Department of Pediatrics 1 and Medical Genetics, Dnipro State Medical University, Ukraine.

Pogribna A. O., PhD Student of the Department of Hospital Pediatrics, Zaporizhzhia State Medical University, Ukraine.

\section{Відомості про авторів:}

Леженко Г. О., А-р меА. наук, професор, зав. каф. госпітальної пеАіатрії, Запорізький Аержавний медичний університет, україна.

Абатуров 0. Є., А-р меА. наук, професор, зав. каф. педіатрії 1 та медичної генетики, Аніпровський Аержавний меАичний університет, Україна.

Погрібна А. О., PhD аспірант каф. госпітальної педіатрії, Запорізький Аержавний медичний університет, Україна.

\section{Сведения об авторах:}

^еженко Г. А., профессор, А-р меА. наук, зав. каф. госпитальной педиатрии, Запорожский государственный медицинский университет, Украина.

Абатуров А. Е., А-р меА. наук, профессор, зав. каф. педиатрии 1 и меАицинской генетики, Анепровский государственный медицинский университет, Украина.

Погребная A. A., PhD аспирант каф. госпитальной педиатрии, Запорожский государственный медицинский университет, Украина.

\section{References}

[1] Lewerenz, J., Ates, G., Methner, A., Conrad, M., \& Maher, P. (2018). Oxytosis/Ferroptosis-(Re-) Emerging Roles for Oxidative Stress-Dependent Non-apoptotic Cell Death in Diseases of the Central Nervous System. Frontiers in neuroscience, 12, 214. https://doi.org/10.3389/ fnins.2018.00214

[2] Toyokuni, S., Yanatori, I., Kong, Y., Zheng, H., Motooka, Y., \& Jiang, L. (2020). Ferroptosis at the crossroads of infection, aging and cancer. Cancer science, 111(8), 2665-2671. https://doi.org/10.1111/cas.14496

[3] Dixon, S. J., Lemberg, K. M., Lamprecht, M. R., Skouta, R., Zaitsev, E. M., Gleason, C. E., Patel, D. N., Bauer, A. J., Cantley, A. M., Yang, W. S., Morrison, B., 3rd, \& Stockwell, B. R. (2012). Ferroptosis: an iron-dependent form of nonapoptotic cell death. Cell, 149(5), 10601072. https://doi.org/10.1016/j.cell.2012.03.042

[4] Stockwell, B. R., Friedmann Angeli, J. P., Bayir, H., Bush, A. I., Conrad, M., Dixon, S. J., Fulda, S., Gascón, S., Hatzios, S. K., Kagan, V. E., Noel, K., Jiang, X., Linkermann, A., Murphy, M. E., Overholtzer, M., Oyagi, A., Pagnussat, G. C., Park, J., Ran, Q., Rosenfeld, C. S., ... Zhang, D. D. (2017). Ferroptosis: A Regulated Cell Death Nexus Linking Metabolism, Redox Biology, and Disease. Cell, 171(2), 273-285. https:// doi.org/10.1016/i.cell.2017.09.021

[5] Vartanian A. A. (2017). Metabolizm zheleza, ferroptoz, rak [Iron metabolism, ferroptosis and cancer]. Russian Journal of Biotherapy, 16(3), 14-20. [in Russian]. https://doi.org/10.17650/1726-9784-2017$\underline{16-3-14-2020}$ 
[6] Ishutina, N. A. (2013). Aktivnost' fosfolipazy A2 i sostoyanie protsessov perekisnogo okisleniya lipidov v perifericheskoi krovi u beremennykh s gerpes-virusnoi infektsiei [Activity phospholipase A2 and state of processes of peroxide oxidation of lipids in the peripheric blood at pregnant with the herpes-virus infection contamination]. Uspekhi sovremennogo estestvoznaniya, (2), 12-14. [in Russian].

[7] Mwachari, C., Nduba, V., Nguti, R., Park, D. R., Sanguli, L., \& Cohen, C. R. (2007). Validation of a new clinical scoring system for acute bronchitis. The international journal of tuberculosis and lung disease, 11(11), 1253-1259.

[8] Miyaji, Y., Sugai, K., Nozawa, A., Kobayashi, M., Niwa, S., Tsukagoshi, H., Kozawa, K., Noda, M., Kimura, H. \& Mori, M. (2015). Pediatric Respiratory Severity Score (PRESS) for Respiratory Tract Infections in Children. Austin Virol and Retrovirology, 2(1), 1009.

[9] Lezhenko, H. O., Abramov, A. V., \& Pohribna, A. O. (2019). The content of apoptosis mediators in children with anemia of inflammation acquired on the background of acute bacterial diseases of respiratory organs. Pathologia, 16(2), 177-181. https://doi.org/10.14739/23101237.2019.2.177112

[10] Lezhenko, H. O., Abramov, A. V., Pohribna, A. O. (2019). Pathogenetic role of nitrosative and oxidative stress in the development of anemia of inflammation in young children. Zdorov'e rebenka, 14(8), 8-12. https:// doi.org/10.22141/2224-0551.14.8.2019.190837

[11] Kenny, E. M., Fidan, E., Yang, Q., Anthonymuthu, T. S., New, L. A., Meyer, E. A., Wang, H., Kochanek, P. M., Dixon, C. E., Kagan, V. E., \& Bayir, H. (2019). Ferroptosis Contributes to Neuronal Death and Functional Outcome After Traumatic Brain Injury. Critical care medicine, 47(3), 410-418. https://doi.org/10.1097/CCM.0000000000003555

[12] Yan, N., \& Zhang, J. (2020). Iron Metabolism, Ferroptosis, and the Links With Alzheimer's Disease. Frontiers in neuroscience, 13, 1443. https:// doi.org/10.3389/fnins.2019.01443

[13] Lezhenko, H. O., \& Pogribna, A. O. (2020). The role of hepcidin in the pathogenetic mechanisms of anemia of inflammation development in young children with acute inflammatory bacterial diseases of the respiratory system. Zaporozhye Medical Journal, 22(4), 473-478. https:/l doi.org/10.14739/2310-1210.2020.4.208356

[14] Reznik, N. L. (2018). Ferroptoz [Ferroptosis]. Khimiya i zhizn', (10), 12-16. [in Russian].

[15] Theil E. C. (2013). Ferritin: the protein nanocage and iron biomineral in health and in disease. Inorganic chemistry, 52(21), 12223-12233. https://doi.org/10.1021/ic400484n

[16] Lal, A. (2020). Iron in Health and Disease: An Update. Indian journal of pediatrics, 87(1), 58-65. https://doi.org/10.1007/s12098-019-03054-8

[17] Quiles Del Rey, M., \& Mancias, J. D. (2019). NCOA4-Mediated Ferritinophagy: A Potential Link to Neurodegeneration. Frontiers in neuroscience, 13, 238. https://doi.org/10.3389/fnins.2019.00238

[18] Lei, P., Bai, T., \& Sun, Y. (2019). Mechanisms of Ferroptosis and Relations With Regulated Cell Death: A Review. Frontiers in physiology, 10, 139. https://doi.org/10.3389/fphys.2019.00139

[19] Mao, H., Zhao, Y., Li, H., \& Lei, L. (2020). Ferroptosis as an emerging target in inflammatory diseases. Progress in biophysics and molecular biology, 155, 20-28. https://doi.org/10.1016/i.pbiomolbio.2020.04.001

[20] Amaral, E. P., Costa, D. L., Namasivayam, S., Riteau, N., Kamenyeva, O., Mittereder, L., Mayer-Barber, K. D., Andrade, B. B., \& Sher, A. (2019). A major role for ferroptosis in Mycobacterium tuberculosis-induced cell death and tissue necrosis. The Journal of experimental medicine, 216(3), 556-570. https://doi.org/10.1084/jem.20181776 